\title{
CONTRIBUTION OF COMPUTATIONAL SIMULATION FOR LAYOUT ANALYSIS IN A WOODEN FURNITURE INDUSTRY ${ }^{1}$
}

\author{
Alexandre Navarro Silva ${ }^{2 *}$, Adolfo Vicente Araújo ${ }^{3}$, Lorraine Cristina Godoy ${ }^{4}$, Luciano José Minette ${ }^{5}$ and \\ Jaqueline Akemi Suzuki ${ }^{5}$
}

\footnotetext{
${ }^{1}$ Received on 07.10.2013 accepted for publication on 01.11.2016.

${ }^{2}$ Universidade Federal de Viçosa, Departamento de Engenharia de Produção e Mecânica, Viçosa, Minas Gerais - Brasil. E-mail:<alexandre.navarro@ufv.br>.

${ }^{3}$ Universidade Federal de Viçosa, Mestrado em Engenharia Agrícola. E-mail: <adolfo.araujo@ufv.br>.

${ }^{4}$ Universidade Federal de Viçosa, Engenheira de Produção. E-mail: <lorrainegodoy@gmail.com>.

${ }^{5}$ Universidade Federal de Viçosa, Departamento de Engenharia de Produção e Mecânica, Viçosa, Minas Gerais - Brasil. E-mail: <minette@ufv.br> and <jaqueline.suzuki@ufv.br>.

*Corresponding author.
}

\begin{abstract}
The objective of this study was to balance the production line and analyze the layout of the sewing sector in a furniture industry. Using the Arena software, a simulation model was constructed that represented the real system consisting of a cellular layout with 3 groups of 5 seamstresses, who produced 57 different types of products divided into three families, in a daily working day of 625 minutes in the months of February to August and 725 minutes in the months of September to January. The model was quantitatively validated among the managers of the studied industry. The obtained results allowed conclusions with an error of less than $1 \%$ in the daily quantity of pieces produced with $99 \%$ statistical confidence. Therefore, three scenarios related to the organization of the work environment and the balancing of the production line were constructed, and those include: i) linear layout, and the balancing allowed the division of five seamstresses for families 1 and 2, and three seamstresses for family 3; ii) study of the layout by processes, so that the best balance was constituted of two groups with seven seamstresses; iii) similar to scenario 2 but with six seamstresses in group 1 and seven seamstresses in group 2. It was verified that the modified, alternative scenario 2 is more advantageous for the organization, since it presents greater productivity compared to all other scenarios and to the real system, so the company can increase its production capacity by simply modifying the layout and organizing the work environment.
\end{abstract}

Keywords: Capacity Management, Line Balancing, Utilization Rate.

\section{CONTRIBUIÇÃO DA SIMULAÇÃO COMPUTACIONAL PARA ANÁLISE DE LAYOUT EM UMA INDÚSTRIA MOVELEIRA}

\begin{abstract}
RESUMO - Objetivou-se realizar o balanceamento da linha de produção e análise do layout do setor de costura em uma indústria moveleira. Utilizando o software Arena, foi construído um modelo de simulação que representasse o sistema real constituido de um layout celular com 3 grupos de 5 costureiras, as quais produziam 57 diferentes tipos de produtos, divididos em três famílias, em uma jornada de trabalho diária de 625 minutos nos meses de fevereiro a agosto e de 725 minutos nos meses de setembro a janeiro. O modelo foi validado quantitativamente junto aos gestores da indústria estudada. Os resultados obtidos indicaram um erro menor de $1 \%$ na quantidade diária de peças produzidas com $99 \%$ de confiança estatística. Assim, foram construídos 3 cenários relacionados à organização do ambiente de trabalho e ao balanceamento da linha de produção, os quais foram: i) layout linear, sendo que o balanceamento realizado permitiu a divisão de 5 costureiras para as famílias 1 e 2 e três costureiras para a família 3; ii) estudo do layout por processos, de forma que o melhor balanceamento constituiu-se de dois grupos com sete costureiras; iii) similar ao cenário 2 , com seis costureiras no grupo 1 e sete costureiras no grupo 2. Concluiu-se que o cenário alternativo 2 modificado
\end{abstract}


é mais vantajoso para a organização, visto que apresenta maior produtividade em comparação a todos os outros cenários e ao sistema real, logo a empresa pode aumentar sua capacidade de produção apenas modificando o layout e organizando o ambiente de trabalho.

Palavras-chave: Gestão da Capacidade; Balanceamento de Linha; Taxa de Utilização.

\section{INTRODUCTION}

In a scenario where there is increasing global competition among companies, more and more companies and industries are forced to perfect their production processes to survive and to remain profitable. In light of this, companies tend to modify their products, invest in innovation, processes, machines, and equipment, in maintenance as well as in the quality of processes and products to fit the needs of the market. They also invest resources into becoming more efficient and effective organizations. Being able to provide high product quality and value to customers has been considered a key element for improving competitiveness in the furniture industry (Toivonen, 2012).

This highly competitive reality makes industrial processes increasingly complex and difficult to analyze. This also increases the risks of decision-making and improvement planning. It can lead to incorrect scenario assessments, the use of unworkable techniques, and the organization to waste resources and efforts. Thus, the way resources are distributed by departments (physical arrangement/layout), the level of inventories used, the productivity of workers, and the way workers are distributed can significantly influence the efficiency of a company. In order to be more competitive, they permanently adopt good strategies from the market and invest in management, which includes certain areas such as layout analysis (Fiedler et al., 2010), line balancing (Antonio et al., 2009), inventory management (Bayou and Korvin, 2008), among others. All this means that productivity is based on continuous internal improvements that reflect externally.

According to Teixeira et al. (2009), the Brazilian furniture industry has great potential to increase its competitiveness in relation to the other exporting countries, and the reasons for growth are the recent investments in new industrial plants, especially designed to meet export demand. The technique of modeling and simulation of discrete events makes it possible to use computers to develop virtual scenarios that mimic the behavior of almost any type of productive system. These scenarios can be modified and tested without compromising the actual system. The generated values support the decision-making, because they allow us to obtain reliable results of hours or days of real processing in few minutes of computational process. In this way, it is possible to achieve the best results with less investment. In addition to a problem analysis tool, simulation is a tool that promotes a better understanding of the systems, serving as a communication medium between analysts, managers and people connected to the operation (Chwif and Medina, 2007).

Through this highly competitive scenario, the use of computer simulation represents resource savings, agility and risk reduction in business decision-making. Pidd (1998) also points out that computer simulation is more feasible than actual changes in the organizational environment due to their low cost, greater reliability and speed of responses while the actual changes/ modifications in the organizational environment generate many efforts, high costs and delay in responses to decision-making. Therefore, modeling and simulation is a tool for analyzing and predicting the behavior of manufacturing systems prior to implementation, and if applied according to an appropriate methodology, will enable statistically reliable results to be obtained to guide managers to identify the best paths during the decision-making process.

In light of the above, the objective of this study was to balance the production line and analysis of the layout of the sewing sector of a furniture industry located in São Geraldo-MG, with the aid of modeling and simulation of the production line. More specifically, this study was intended to create a model capable of describing the current production system and analyzing productivity based on the theory of Discrete Event Systems (SED).

\section{MATERIALS AND METHODS}

This work aims to contribute to the equation of the central problem through research and analyzes that can help the agents in the decision-making and in the solution of the investigated problem. In addition, there 
is a wide and explicit interaction between researchers and the production managers of the organization under study, and this interaction results in the definition of priorities for the problems to be researched and the solutions to be implemented.

In order to achieve the proposed objectives, we have started with the planning for the execution of this project, which begins with the characterization of the study area, followed by the process knowledge of each model, production flow analysis, establishment of guidelines for data collection, data collection, and statistical analysis of the data and construction of the computational model. All this in order to finally analyze alternative layout scenarios and propose better sequencing of the production line.

\subsection{Knowledge of the company and of its processes}

The present work was carried out in the sector of upholstery backstitching in a furniture industry located in São Geraldo/MG, in order to evaluate layout scenarios and a better sequence of the processes of each activity of the manufactured upholstery models, in order to provide increasing productivity in the industry.

The first stage in the development of the project was to acquire knowledge on the company, which operates from Monday to Friday, with operating hours between 7:00AM and 5:20PM. The current configuration of the backrest seam sector system is composed of 15 seamstresses distributed in three groups, with five seamstresses in each. In addition, we have also observed the layout of the backrest sewing sector, the products that are produced and the sequence of its productive processes. In order to do this, we have conducted visual observations in visits and unstructured interviews to employees, to better understand how the operation of production occurs and which major models of manufactured stews.

\subsection{Production Flow Analysis}

Based on the unstructured interview with the production supervisors, we have understood the processes of the 24 models of most produced upholstery, as verified by the $\mathrm{ABC}$ classification, and that pass through the sector of the seam of the backrest. For a more detailed understanding of the interrelationship of the processes of each model, the Production Flow Analysis (PFA) technique proposed by Burbridge (1991) was used and validated by the sector's production supervisors from the sewing industry.

Thus, in the study in question, the processes of each model were evaluated by elaborating the production sequence and grouping the models that had either the same productive process or similar processes. The use of this technique suggested the formation of three families confirmed and approved by the supervisor of the production sector of the studied company. The simplified production flowchart for the products in each family is shown in Figure 1.

\subsection{Establishment of guidelines for data collection}

We have verified that the production of upholstery follows a batch production process and each model produced has different quantities. This is because the company has a production process based on products made to order. Therefore, the items are produced according to the demand, so that the models present a great variety in the produced quantities.

Through the organization's historical data, we have verified the most productive models for the company and from that point, the guidelines for data collection were elaborated which was planned following the ABC classification. Thus, data collection was performed for 24 models, which represent $95 \%$ of the produced quantities. As recommended by Chwif and Medina (2007)

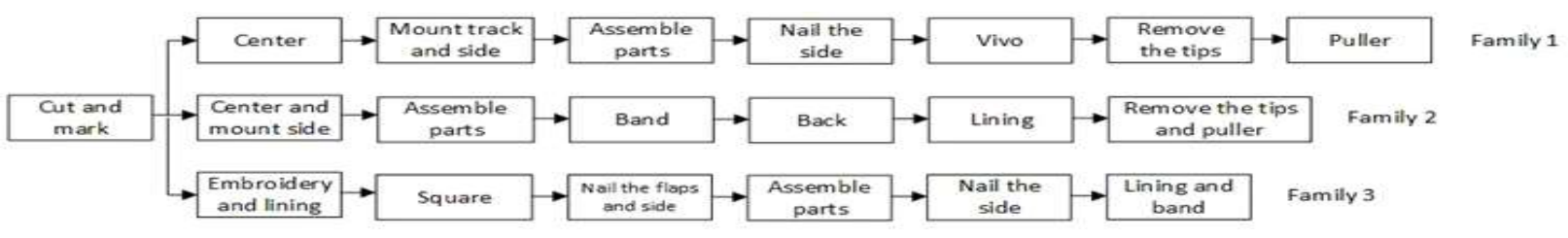

Figure 1 -Simplified representation of the production flow of families 1, 2 and 3.

Figura 1-Representação simplificada do fluxo de produção dos produtos nas famílias 1, 2 e 3. 
and by Szymankiewicz et al. (1998), the sample size was between 100 and 200 observations for each family and activity, which is enough for most of the simulation studies.

\subsection{Data Collection and Statistical Analyzes}

In the present work, the input variables were the productive times of each activity involved in the production. All these data were collected in loco on different days and shifts, because there is variability in the productivity of seamstresses according to the day and the shift in which they work. Then, the data collection was performed in order to obtain a larger sample and a frequency distribution of values as close as possible to reality.

\subsubsection{Analysis of Outliers}

Data sampling will always be subject to errors in the collection or occurrence of unusual events. These are called outliers, and they are atypical values that may interfere with the results of the analysis. Thus, as the objective of identifying these outliers of the sample, we have elaborated a boxplot which is a graphical representation of the frequency distribution of the data. Before deciding what should be done about the outlier observations, it is convenient to be aware of the causes that lead to their appearance. According to Law and Kelton (1991) the simplest way to deal with these observations is to eliminate them and this procedure was carried out in this work.

\subsubsection{Comparison between upholstery models}

In order to evaluate whether the models within each family had the same average time in the activities of the production process, a Variance Analysis (ANOVA) was performed as a way to verify if the observed difference between sample averages would be due only to the random variations between a sample and another, or whether the data come from populations with truly different averages. For the activities that presented p-values higher than $10 \%$ among the models, the Tukey test was performed with a significance level of $10 \%$. These analyzes were done in SAS/STAT software, licensed for use by the Federal University of Viçosa.

\subsubsection{Adjustment of probability distributions}

In order to evaluate which probability distribution each set of activity/model data, we have performed the chi-square test using the ARENA software Input
Analyzer. This tool provides statistical adjustments to a set of experimental data and allows one to analyze actual data on the operation of the process and choose the best statistical distribution that applies to them. The best fit probability distribution was adopted for each data set, and for all of these, the p-value was higher than the significance level of $10 \%$ for the chisquare test.

\subsection{Construction of the computer model}

The implementation of the computer model adopted in this work followed the steps recommended by CHWIF and MEDINA (2007). In this methodology, after the formulation of the problem, the collection of the input data and its statistical treatment, the design of the model is performed using a commercial simulation software, in our case the ARENA was used. During this procedure, checks (in regards to the behavior of the model in the computer) and validations (in regards to the representation of the real system by the model) are made. In this study, the verification of the model was performed empirically through graphic visualization, and the validation was performed by comparing the number of pieces produced in the simulation with the real historical number.

To identify the minimum number of simulations, 30 iterations (replications) were considered which theoretically represent 30 working days, considering the working time ( 625 minutes per day) and the stops (15 minutes for snacks at 10:00AM and 3:00PM. 70 minutes for lunch at 12:15PM.). By means of this pilot sample, the accuracy of the model was calculated for the number of produced pieces, by means of the confidence interval (Eq. 1).

$$
x \pm h=t_{n-1, a / 2} \frac{s}{\sqrt{n}}
$$

In which:

$x$ is the sample average;

$h=t_{n-1, \alpha / 2} \frac{s}{\sqrt{n}}$-is half of the interval, so-called precision;

$t_{\mathrm{n}-1, \alpha / 2}$ is the $(1-\alpha / 2)$ percentile of the Student $\mathrm{t}$ distribution with $\mathrm{n}-1$ degrees of freedom;

$s$ is the sample standard deviation;

$n$ is the number of inputs in the sample. 
Since the precision (h) of the model was of 3.58 parts, considering a level of significance of $99 \%$, we have verified that the number of 30 replications was adequate to obtain reliable conclusions from the constructed model.

\subsection{Construction of the scenarios for decision making}

The changes in the model were performed in order to evaluate possible scenarios to improve productivity. Changes in the productive layout were studied and it was decided to develop two alternative scenarios for the simulation. The alternative scenarios are based on the modification of the cellular layout, currently used in the industry, for product layout and for process layout.

Current Scenario: The current scenario consists of the cellular layout, illustrated in Figure $2 \mathrm{a}$, in which the by-products of each model run through five seamstresses until they become finished products.

Alternative scenario 1 - Layout by product: Alternative scenario 1 consists of the product layout (linear), shown in Figure 2b, in which the models of each of the families follow a production line in sequence. In this layout, the production process is continuous, and the product to be processed moves while the seamstresses remain fixed and they are arranged according to the sequence of operations.

Alternative scenario 2 - Layout by process: Alternative scenario 2 consists of a (functional) process layout, as shown in Figure 2c. In this scenario, the models of all families go through groups with the same function.

\section{RESULTS}

\subsection{Treatment of data}

Among the collected data, the analysis of 18 outliers were withdrawn in only 4 activities, with three Family 1 activities (coasts, joining parts and sides) and a Family 2 activity (assemble the back).

By means of the Analysis of Variance (ANOVA) and the Tukey test, we have verified that in 21 activities there was a significant difference between the average time of the models at the level of $10 \%$ of significance, namely 6 activities for Family 1 (center pieces, assemble sides, side sewing, presponto and puller), 8 activities
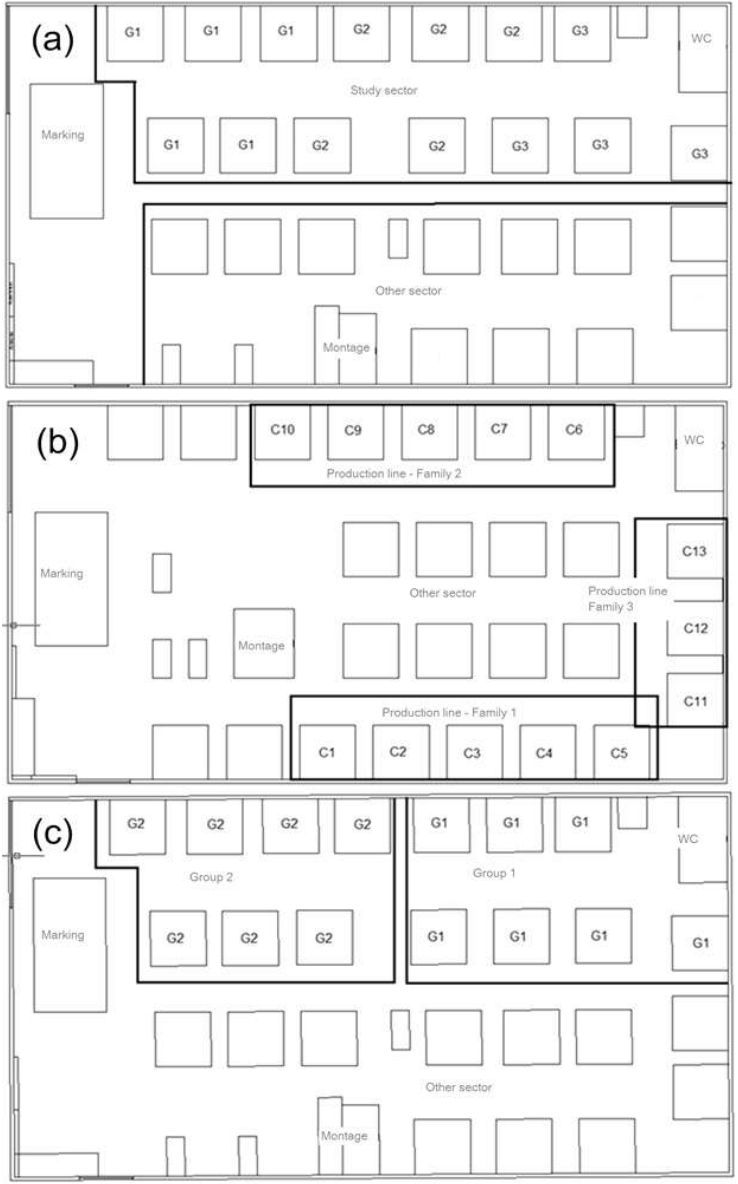

Figure 2 - Representation of the layout currently used by the studied industry (a), alternative scenario 1 , linear layout (b) and alternative scenario 2 , process layout (c).

Figura 2 - Representação do layout atualmente utilizado pela indústria estudada (a), do cenário alternativo 1, layout por produto (b) e do cenário alternativo 2, layout por processo (c).

for Family 2 (center pieces, assemble sides side sewing, join parts, band, sew back, lining and puller) and 7 activities for Family 3 (liner, puller, live, square, side sew, join parts and strip). Thus, adjustments of probability distributions were made for each model separately, i.e. each model with average significantly different from the others underwent an adjustment of distribution to be inserted separately in the computer model.

\subsection{Verification and validation of the computer model}

After the construction of the computer model, a simulation was performed with a pilot sample of 30

Revista Árvore. 2017;41(2):e410201 
replications in order to evaluate whether the model was valid, i.e. whether it represented the reality of the company. Results were obtained from the computer model with $99 \%$ confidence interval for the number of pieces produced and the precision obtained was approximately 4 pieces, which was considered a very satisfactory precision. These replications generated results for comparison with the actual data of the factory, considering that the industry works with differentiated production throughout the year, and between February and August the production was carried out in 625 minutes per day and between September and January, in 725 minutes per day.

Due to the fact that industry produces their items to order, effective daily demand is variable. Between February and August, production was fixed at 540 items/ day and between September and January, it increased to 720 items/day. Comparing the parameters of the actual operation (540 and 720 items/day in each period of the year) and the parameters generated by the computational model (537 and 718 items per day in each period of the year), it was possible to verify great proximity between the real data and the obtained results, which makes the model valid for analysis and decisionmaking.

\subsection{Experimentation and analysis of results}

\section{Real scenario}

The real scenario consists of the cell layout which contains 5 seamstresses in each cell, and these produce pieces from all product families. Once the model was validated, we have obtained the utilization rates of each seamstress (Figure 3 ) with an average production of 537 items per day in the months of February to August, and of 718 items per day in the months of September to January, showing heterogeneity of the use of the cells, which has been confirmed as a good representation of reality by industry production supervisors.

\section{Alternative scenario 1 - layout by product}

Alternative scenario 1 , which consists of the product-based layout (linear), was elaborated by assigning an activity to each seamstress; then the bottlenecks were checked and how the employees were being allocated. Next, from this analysis of bottlenecks and allocation of employees, we managed to achieve the balancing of the production line, joining activities in order to obtain the same use of each

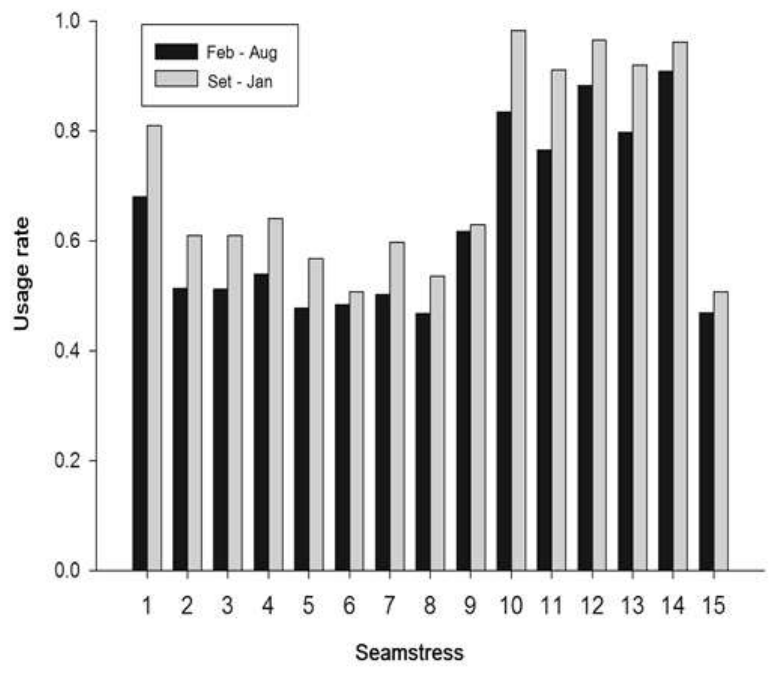

Figure 3 - Utilization rate of the seamstresses obtained by the real scenario for the months from February to August (black color) and from September to January (gray color).

Figura 3 - Taxa de utilização das costureiras obtida pelo cenário real para os meses de fevereiro a agosto (cor preto) e para os meses de setembro ajaneiro (cor cinza).

seamstress and with the purpose of obtaining greater productivity. Thus, the simulation with 30 replications resulted in the production of 637 items per day and in Figure 4 it is possible to verify the balanced utilization rate among the employees.

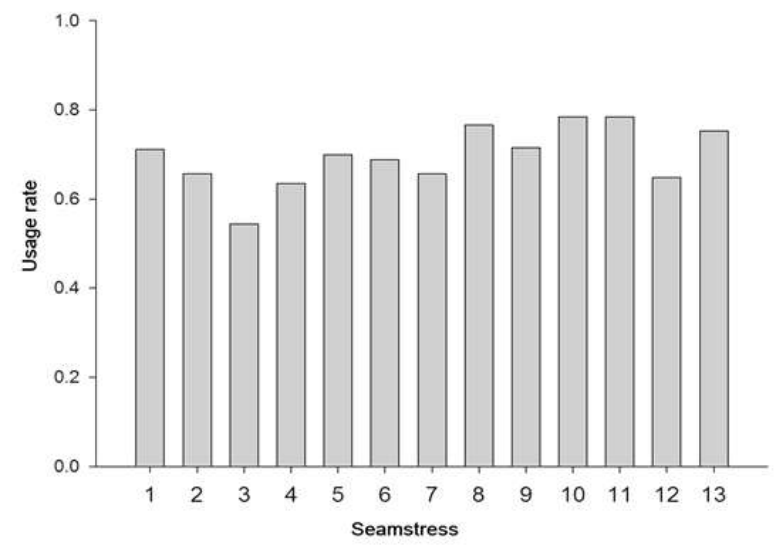

Figure 4 - Utilization rate of the seamstresses obtained by the alternative scenario 1 , with a linear layout by product.

Figura 4 - Taxa de utilização das costureiras obtida pelo cenário alternativo 1, layout por produto. 


\section{Alternative scenario 2 - layout by process}

The alternative scenario 2 , which consists of the (functional) process-based layout, was elaborated through an adaptation of the line balancing methodology presented in Gaither and Frazier (2002) and Slack et al. (2009). A balancing was also performed using the weighted average of the times of each activity by the quantities produced by each model. This balancing resulted in two processes with five activities per process. As the line balancing resulted in two processes with the same number of dressmakers and there was availability of 15 seamstresses, a specific number of seamstresses were adopted for each process.

Therewith, through the simulation with 30 replications, we have achieved an average production of 720 items per day and the utilization rate of the seamstresses of Group 1 resulted in $75 \%$, and of those in Group 2, in 87\%.

In addition, it was verified that both the minimum and the maximum number of pieces produced were 720 items per day, which leads to verifying possible idleness among the seamstresses. Therewith, the organization can choose to produce more than 720 items per day or to reduce the number of employees to thirteen, six in group 1 (who presented lower utilization rate) and seven in group 2, which would result in a daily production of 716 items per day on average, and at a utilization rate of $89 \%$ of the seamstresses in Group 1 and $72 \%$ of the seamstresses in Group 2.

\section{DISCUSSION}

The proximity of the results obtained by the model when compared to the real system, allowed us to obtain reliable conclusions from the model and its variations. Thus, it was possible to verify that the real scenario corresponds to the production reality of the industry with ten seconds of movement time between the processes and fifteen seamstresses, resulting in a daily production of 36 items per seamstress between the months of February and August, and 48 between September and January (Table 1).

In alternative scenario 1 , the movement time is reduced to 2 seconds due to the layout per production line, and for this scenario only thirteen seamstresses would be required to achieve a daily production of 637 items, each of which would produce 49 items. For alternative scenario 2, we have considered that the movement time remains ten seconds because the layout would be cellular rather than linear but production would reach 720 daily items with fourteen seamstresses, each of which would produce 51 items per day. As a modification of scenario 2 , the reduction of one seamstress can be interesting, since the industry could maintain the workforce throughout the year without the need for overtime, for example by relocating two employees to another sector.

In relation to scenario 2 , this results in greater productive capacity and a certain idleness of the seamstresses. Thus, the organization may choose to either produce more than 720 items per day with fourteen seamstresses or to reduce the number of employees to thirteen.

Therefore, it is possible to observe that the modified alternative scenario 2 is more advantageous for the organization, since it presents higher productivity during the first months compared to the real scenario, so the company can increase its production capacity only by modifying the layout and organizing the production area. In relation to the last months, production reaches the goal with fewer employees and without overtime, therefore reducing costs significantly.

\section{CONCLUSION}

The modeling and simulation were able to assist in the visualization of the operation of the full system,

Table 1 - Comparing the results obtained by the scenarios. Tabela 1 - Comparação dos resultados obtidos nos cenários.

\begin{tabular}{lcccc}
\hline \multicolumn{1}{c}{ Scenarios } & $\begin{array}{c}\text { Simulation } \\
\text { time (min) }\end{array}$ & $\begin{array}{c}\text { Production } \\
\text { (items/day) }\end{array}$ & $\begin{array}{c}\text { Movement } \\
\text { time between } \\
\text { activities (s) }\end{array}$ & $\begin{array}{c}\text { Number of } \\
\text { seamstresses } \\
\text { per seamstress }\end{array}$ \\
\hline Real Scenario (Feb-Aug) & 625 & 540 & 10 & 15 \\
Real Scenario (Sep-Jan) & 725 & 718 & 10 & 36 \\
Alternative Scenario 1 & 625 & 637 & 2 & 15 \\
Alternative Scenario 2 & 625 & 720 & 10 & 13 \\
Alternative Scenario 2 modified & 625 & 716 & 10 & 14 \\
\hline
\end{tabular}


allowing better perception of how the cell would function in a real situation for the operators and managers of the company, thus facilitating the approval of the proposed modifications. The presented case proved that the simulation tool can help in the decision-making process of a given company.

The understanding of the production process was a direct benefit of the computer modeling and simulation process but it was also possible to evaluate gains in important indicators in process management. Through the results generated by the simulation, we have obtained validation of the benefits generated by the implementation of the principles of manufacturing by processes, as well as its importance in the elimination of movements, stocks, waiting time and overtime. In addition, it was possible to observe the production capacity of the company, and to verify whether it meets its current demand.

For future studies, we suggest a simulation using a longer period of time, with the inclusion of more characteristics of the process that were not considered in the present work, such as for example the absence of operators in working area, unforeseen set-ups and variations in demand.

\section{REFERENCES}

Antonio KWL, Richard CMY, Tang E. The complementarity of internal integration and product modularity: An empirical study of their interaction effect on competitive capabilities. Journal of Engineering and Technology Management. 2009;26:305-26.

Bayou ME, Korvin A. Measuring the leanness of manufacturing systems - A case study of Ford Motor Company and General Motors. Journal of Engineering and Technology Management. 2008;25:287-304.
Burbidge JL. Production flow analysis for planning group technology. Journal of Operations Management. 1991;10(1):5-27.

Chwif L, Medina AC. Modelagem e simulação de eventos discretos, teoria \& aplicações. $2^{a}$. ed. São Paulo: 2007.

Fiedler NC, Wanderley FB, Nogueira M, Oliveira JTS, Guimarães PP, Alves RT. Otimização do layout de marcenarias no sul do espírito santo baseado em parâmetros ergonômicos e de Produtividade. Revista Árvore. 2009;33(1):161-70.

Gaither N, Frazier G.

Administração da produção e operações. São Paulo: Thomson Learning; 2002.

Law AM, Kelton DW. Simulation modeling \& analysis. $2^{\mathrm{a}}$ ed. London: McGraw-Hill; 1991.

Pidd M. Modelagem empresarial - ferramentas para tomada de decisão. Porto Alegre: Bookman; 1998.

Slack N, Chambers S, Johnston R. Administração da produção. 2a . ed. São Paulo: Atlas; 2009.

Szymankiewicz J, Mcdonald JE, Turner K. Solving business problems by simulation. $2^{\mathrm{a}}$ ed. London: McGraw-Hill; 1998.

Teixeira TOB, Silva ML, Jacovine LAG, Valverdes R, Silva JC, Pires VAV. A percepção sobre o uso da madeira de eucalipto pelos fabricantes do polo moveleiro de Ubá-MG. Revista Árvore. 2009;33(5):969-75.

Toivonen RM. Product quality and value from consumer perspective-An application to wooden products. Journal of Forest Economics. 2012;18:157-73. 